\title{
ANALISIS KEBUTUHAN KOMPETENSI PEKERJA INDUSTRI KULIT/ALAS KAKI MENYONGSONG ERA INDUSTRI 4.0
}

\author{
Taukhid W Broto ${ }^{1)}$, Risang Pujiyanto \\ 1, Jurusan Teknologi Pengolahan Karet dan Plastik, Politeknik ATK Yogyakarta

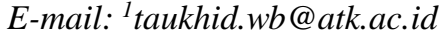

\begin{abstract}
Industry 4.0 competency model has three areas of competence as salience, there is Information Systems, Computer Science, and Engineering. It hence requires adaptability to SKKNI Golongan Pokok Industri Kulit, Barang dari Kulit and Alas Kaki to accommodate these three areas as part of the competence that must be owned by industrial workers. The analysis of competency needs of leather industry and footwear industry aims to produce SKKNI accordance recommendation to the concept of industry standard 4.0. The method used is point-to-point correlation between predictors and criteria initiated by (Bartram, 2005) and further developed by (Prifti, Knigge, Kienegger, \& Krcmar, 2017). In the end SKKNI which is embraced through the application of this recommendation will be use as reference for the formal and non-formal curriculum education improvement to prepare industry workforce towards industry 4.0 era.
\end{abstract}

Keywords: SKKNI, Competency, Leather Industry, Footwear Industry

\begin{abstract}
Abstrak
Model kompetensi Industri 4.0 memiliki tiga bidang kompetensi yang menjadi ciri khasnya yaitu bidang Sistem Informasi, Ilmu Komputer, dan Teknik dalam satu kesatuan. Hal tersebut menuntut penyesuaian terhadap SKKNI Golongan Pokok Industri Kulit, Barang dari Kulit dan Alas Kaki, supaya dapat memenuhi ketiga bidang kompetensi tadi sebagai bagian dari keahlian yang perlu dimiliki oleh para pekerja industri. Analisis kebutuhan kompetensi industri kulit/alas kaki bertujuan menghasilkan rekomendasi penyesuaian SKKNI yang ada terhadap konsep standar industri 4.0. Metode yang digunakan adalah point-to-point correlation antara predictor dan kriteria yang diusulkan oleh (Bartram, 2005) dan dikembangkan lebih lanjut oleh (Prifti et al., 2017). Pada akhirnya SKKNI yang dihasilkan melalui penerapan rekomendasi ini nantinya dapat menjadi acuan penyempurnaan kurikulum Pendidikan formal maupun non-formal guna mempersiapkan tenaga kerja industri menyongsong era industri 4.0.
\end{abstract}

Kata kunci: SKKNI, Kompetensi, Industri Kulit, Industri Alas Kaki

\section{PENDAHULUAN}

Pada tanggal 4 April 2018, Indonesia telah menyambut industri 4.0 melalui peluncuran sebuah peta jalan dengan nama "Making Indonesia 4.0" oleh Presiden Joko Widodo, bersamaan dengan pembukaan Indonesia Industrial Summit 2018 di Jakarta Convention Centre,
Senayan, Jakarta Pusat (Gareta, 2018). Konsep Industri 4.0 sendiri lebih mengarah kepada istilah yang digunakan Pemerintah Federal Jerman untuk memperkuat industri manufaktur di wilayahnya dan untuk menghadapi tantangan global melalui pemanfaatan internet serta teknologi informasi dan komunikasi. Konsep Industri 4.0 sendiri 
lebih mengarah kepada istilah yang digunakan Pemerintah Federal Jerman untuk memperkuat industri manufaktur diwilayahnya demi menghadapai tantangan global melalui pemanfaatan internet dan teknologi informasi lainnya (Kagermann, Wahlster, \& Helbig, 2013).

Era Industri 4.0 tidak hanya memberikan dampak positif berupa peningkatan produktivitas dan efisiensi namun juga memberikan dampak negatif berupa hilangnya 50 juta lapangan kerja, sebagaimana dikemukakan oleh Menteri Perencanaan Pembangunan Nasional, Bambang PS Brodjonegoro (Jatmiko, 2018). Hal tersebut tidak terlepas dari karakteristik Industri 4.0 itu sendiri yang cenderung padat teknologi dan pada akhirnya dapat menciptakan kesenjangan antara kompetensi beserta keahlian yang dibutuhkan oleh industri dan calon pencari kerja (Jackson, 2010). Meskipun kondisi tersebut dirasakan berat, masih ada harapan dengan munculnya peluang kerja baru yang selama ini belum ada atau belum banyak berkembang. Dan solusi permasalahan tersebut diantaranya melalui pembaruan bidang kompetensi untuk dikuasai guna menjawab tantangan kedepan (Williams, 2005).

Terkait kebutuhan kompetensi pekerja dalam menghadapi era Industri 4.0 ini mulai banyak dilakukan penelitiannya. Penelitian yang dilakukan terkait standar kompetensinya sendiri (Bartram, 2012; Prifti et al., 2017), ada juga yang secara langsung mengarah kepada penerapannya di industri saat ini (Milagros Diaz Bermudez, 2017), dan ada juga difokuskan pada pembenahan kurikulum Pendidikan demi menyiapkan tenaga kerja industri dalam menghadapi tantangan kedepan (Enke et al., 2018).Di Indonesia sendiri sudah ada standar kompetensi yang menjadi acuan keahlian bagi pekerja industri yaitu Standar Kompetensi Kerja Nasional Indonesia (SKKNI). Standar ini dibuat dan ditetapkan sebagai amanat Undang-undang Nomor 13 Tahun 2003 tentang Ketenagakerjaan Pasal 8 Ayat 1
Huruf c bahwa perencanaan tenaga kerja disusun atas dasar informasi ketenagakerjaan yang antara lain meliputi pelatihan kerja termasuk kompetensi kerja (Sekretaris Negara Republik Indonesia, 2003). Berturut-turut kemudian dikeluarkan Peraturan Pemerintah Nomor 31 Tahun 2006 tentang Sistem Pelatihan Kerja Nasional, Peraturan Presiden Nomor 8 Tahun 2012 tentang Kerangka Kualifikasi Nasional Indonesia, dan Peraturan Presiden Nomor 18 Tahun 2015 tentang Kementerian Ketenagakerjaan.

Petunjuk teknis penerapan SKKNI selanjutnya diatur melalui Peraturan Menteri Tenaga Kerja dan Transmigrasi Nomor 8 Tahun 2012 tentang Tata Cara Penetapan SKKNI dan Peraturan Menteri Ketenagakerjaan Nomor 21 Tahun 2014 tentang Penerapan Kerangka Kerja Kualifikasi Nasional Indonesia. Di kategori Industri Pengolahan, Golongan Pokok Industri Kulit, Barang dari Kulit dan Alas Kaki terdapat tiga buah SKKNI yaitu SKKNI Industri Kulit dan Kulit Buatan, termasuk Pencelupan Kulit Berbulu Kelompok Industri Pengawetan Kulit (Kementerian Tenaga Kerja dan Transmigrasi, 2013), SKKNI Industri penyamakan Kulit Subbidang Proses Produksi (Kementerian Ketenagakerjaan, 2016a), dan SKKNI Bidang Industri Alas Kaki (Kementerian Ketenagakerjaan, 2016b). Terkait SKKNI yang telah disusun, kajian Biro Perencanaan Kementerian Perindustrian (2014) menyatakan bahwa standar kompetensi yang bersifat statis dan masih jauh dari kebutuhan ketrampilan yang ada merupakan salah satu permasalahan pemenuhan SDM Industri manufaktur. Hal ini tentu merupakan masalah yang harus segara diatasi untuk mengantisipasi dampak negatif industri 4.0.

Kebutuhan akan kompetensi dibidang teknologi informasi dan komunikasi untuk menghadapi industri 4.0 menjadikan SKKNI yang ada perlu dikaji ulang. Lantas, seperti apa kebutuhan kompetensi pekerja industri kulit/alas kaki guna 
menyongsong era industri 4.0? Berdasarkan latar belakang masalah sebagaimana telah diuraikan di atas, maka yang menjadi rumusan masalah penelitian adalah: Bagaimana kebutuhan standar kompetensi pekerja industri kulit/alas kaki dalam Industri 4.0?

\section{METODE PENELITIAN}

Penelitian ini merupakan penelitian kualitatif dengan menggunakan metode Focus Group Discussion untuk mengeksplorasi masalah spesifik mengenai kebutuhan standar kompetensi pekerja industri kulit/alas kaki dalam Industri 4.0. Pengumpulan data dilakukan secara berurutan, untuk menentukan topik diskusi dilakukan terlebih dahulu literature review mengenai kompetensi yang dibutuhkan dalam industri 4.0. Selanjutnya dilakukan penilaian persepsi anggota Forum Group Discusion yang merupakan penyusun dan pengguna SKKNI terhadap hasil literature review melalui point-to-point correlation.

\section{HASIL DAN PEMBAHASAN}

Biro Perencanaan Kementerian Perindustrian dalam buku Perencanaan Kebutuhan Sumber Daya Manusia Industri dalam Rangka Pembangunan Industri Nasional 2015-2035 (2014:100), telah memproyeksikan kebutuhan sumber daya manusia (SDM) Industri sektor manufaktur untuk tahun 2013 sampai dengan tahun 2035, dimana jumlah SDM Industri pada tahun 2035 diproyeksikan total sejumlah 29.290.000 orang.

Grafik 1. Proyeksi Persentase SDM Industri Manufaktur, 2013-2035

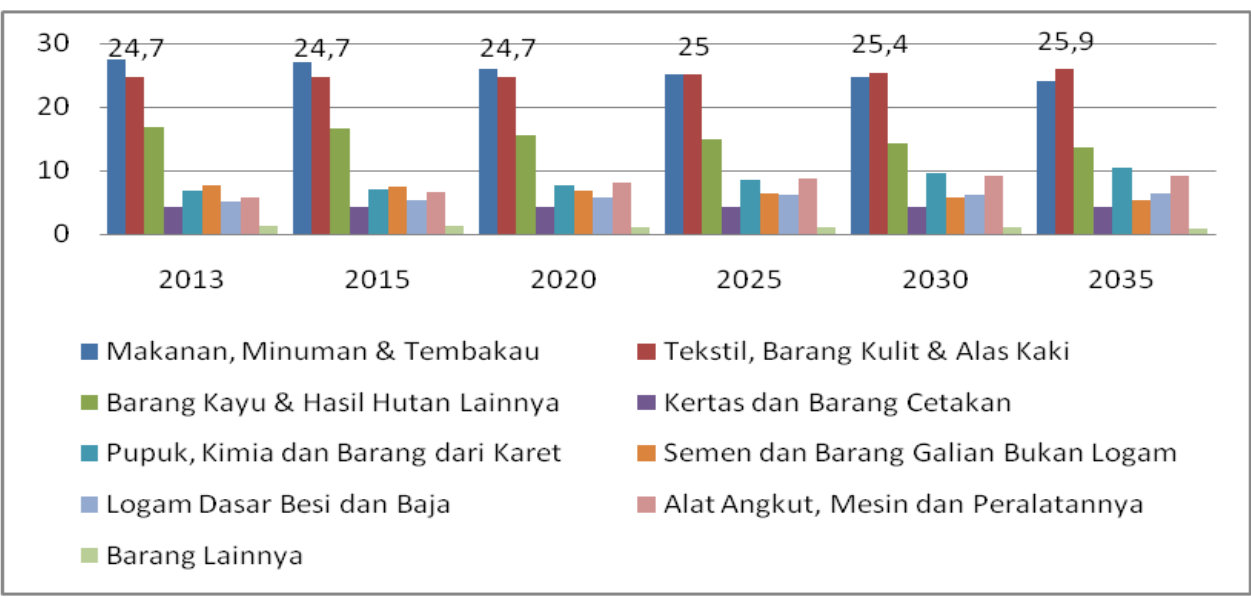

Sumber : Biro Perencanaan diolah (2014)

Namun permasalahan SKKNI yang bersifat statis dan belum sesuai dengan kebutuhan industri akan menjadikan pemenuhan kebutuhan SDM sulit terpenuhi. Untuk itu kaji ulang SKKNI yang sudah ada khususnya SKKNI kategori Industri Pengolahan, Golongan Pokok Industri Kulit, Barang dari Kulit dan Alas Kaki menjadi hal yang mendesak dilakukan. Pasal 19 Peraturan Menteri Tenaga Kerja dan Transmigrasi Nomor 5 Tahun 2012 Tentang Sistem Standardisasi Kompetensi Kerja Nasional, menyebutkan Kaji ulang SKKNI adalah untuk memelihara validitas dan reliabilitas SKKNI melalui melihat aspek kesesuaian dengan:

1. perubahan dan perkembangan ilmu pengetahuan dan teknologi;

2. perubahan cara kerja; dan

3. perubahan lingkungan kerja dan persyaratan kerja.

Berdasarkan literature review, topik kompetensi yang digunakan dalam rekomendasi kaji ulang SKKNI industri kulit/alas kaki adalah Model Kompetensi Industri 4.0 yang ditawarkan oleh (Prifti et al., 2017) sebagai pengembangan lebih 
lanjut dari model kompetensi SHL Universal Competency Framework (UCF) (Bartram, 2005, 2012). Prifti et al (2017) dalam penelitiannya memberikan batasan sebagai berikut :

"...we want to offer an overview of the competencies that should be taught to individuals for successfully working in I4.0. Therefore we apply the behavioralbased approach since it offers the best fit for our purpose, by giving also the possibility to describe the relationship between competencies as constructs on the one hand, and psychological constructs such as motives and personality traits on the other."

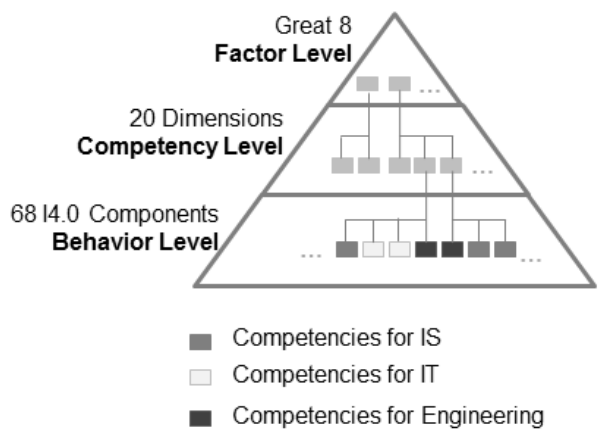

Sumber : Prifti et al., 2017

Tabel 1.Model Kompetensi dalam Industri 4.0

\begin{tabular}{|c|c|c|c|c|}
\hline \multirow[t]{2}{*}{ Big Eight } & Competency Dimensions & \multicolumn{3}{|c|}{ Competencies } \\
\hline & & $\begin{array}{l}\text { Information } \\
\text { Systems } \\
\text { (IS) }\end{array}$ & $\begin{array}{l}\text { Computer } \\
\text { Science }\end{array}$ & Engineering \\
\hline \multirow[t]{2}{*}{$\begin{array}{l}\text { A. Leading } \\
\text { Deciding }\end{array}$} & $\begin{array}{l}\text { 1. Deciding and } \\
\text { Initiating Action }\end{array}$ & \multicolumn{3}{|c|}{$\begin{array}{l}\text { 1. Decision Making } \\
\text { 2. Taking Responsibility }\end{array}$} \\
\hline & $\begin{array}{lll}\text { 2. } & \text { Leading and } \\
& \text { Supervising } \\
\end{array}$ & \multicolumn{3}{|c|}{ 1. Leadership Skills } \\
\hline \multirow[t]{2}{*}{$\begin{array}{l}\text { B. Supporting and } \\
\text { Cooperating }\end{array}$} & $\begin{array}{l}\text { 1. Working } \\
\text { People }\end{array}$ & \multicolumn{3}{|c|}{$\begin{array}{ll}\text { 1. } & \text { Teamwork } \\
\text { 2. } & \text { Collaborating with Others } \\
\text { 3. } & \text { Communicating with People }\end{array}$} \\
\hline & $\begin{array}{ll}\text { 2. } & \text { Adhering } \\
\text { Principles } \\
\text { Values }\end{array}$ & \multicolumn{3}{|c|}{$\begin{array}{ll}\text { 1. } & \text { Respecting Ethics } \\
\text { 2. Environmental Awareness } \\
\text { 3. }\end{array}$} \\
\hline \multirow[t]{4}{*}{$\begin{array}{l}\text { C. Interacting and } \\
\text { Presenting }\end{array}$} & $\begin{array}{l}\text { 1. Relating } \\
\text { Networking }\end{array}$ & \multicolumn{3}{|c|}{$\begin{array}{ll}\text { 1. } & \text { Compromising } \\
\text { 2. } & \text { Creating Business Networks }\end{array}$} \\
\hline & & \multicolumn{3}{|c|}{$\begin{array}{ll}\text { 3. } & \text { Maintaining } \\
& \text { Relationships }\end{array}$} \\
\hline & $\begin{array}{ll}\text { 2. } & \text { Persuading and } \\
\text { Influencing }\end{array}$ & \multicolumn{3}{|c|}{$\begin{array}{l}\text { 1. Negotiating } \\
\text { 2. Emotional Intelligence }\end{array}$} \\
\hline & $\begin{array}{ll}\text { 3. } & \text { Presenting and } \\
\text { Communicating } \\
\text { Information }\end{array}$ & \multicolumn{3}{|c|}{$\begin{array}{ll}\text { 1. } & \text { Presentation } \\
& \text { Communication Ability }\end{array}$} \\
\hline $\begin{array}{l}\text { D. Analysing and } \\
\text { Interpreting }\end{array}$ & $\begin{array}{ll}\text { 1. } & \text { Writing and } \\
& \text { Reporting }\end{array}$ & \multicolumn{3}{|c|}{$\begin{array}{l}\text { 1. Targeted/Technical } \\
\text { Communication } \\
\text { 2. Literacy }\end{array}$} \\
\hline
\end{tabular}

Prifti et al menggunakan pendekatan perilaku dalam menentukan kompetensi industri 4.0 dan hal ini sesuai untuk digunakan dalam kajian ini dengan mengingat bahwa pendekatan perilaku meyakini bahwa kompetensi dapat diajarkan melalui pembelajaran dan pengembangan. Point-to-point Correlation dilakukan dengan melihat kesesuaian antara model kompetensi Industri 4.0 yang ditawarkan oleh (Prifti et al., 2017) yang meliputi 3 (tiga) tingkat kompetensi yaitu Big Eight competency sebagai tingkat pertama, 20 dimensi kompetensi sebagai tingkat kedua, dan kompetensi industri 4.0 sebagai tingkat ketiga dengan unit kompetensi yang terdapat dalam SKKNI Industri Alas Kaki, Pengawetan Kulit dan Penyamakan Kulit. Unit kompetensi dapat diartikan sebagai job role, fungsi pekerjaan untuk menghasilkan produk atau jasa yang didalamnya antara lain termuat elemen kompetensi (job task) dan kriteria unjuk kerja (performance standard). 


\begin{tabular}{|c|c|c|}
\hline & $\begin{array}{l}\text { 2. Applying Expertise } \\
\text { and Technology }\end{array}$ & $\begin{array}{l}\text { 1. IT and Technology Affinity } \\
\text { 2. Economics } \\
\text { 3. Extract Business Value from } \\
\text { Social Media }\end{array}$ \\
\hline & 3. Analysing & $\begin{array}{ll}\text { 1. } & \text { Problem Solving } \\
\text { 2. } & \text { Optimization } \\
\text { 3. } & \text { Analytical Skills } \\
\text { 4. } & \text { Cognitive Ability } \\
\end{array}$ \\
\hline \multirow[t]{3}{*}{$\begin{array}{ll}\text { E. Creating and } \\
\text { Conceptualizing }\end{array}$} & $\begin{array}{lll}\text { 1. } & \text { Learning and } \\
& \text { Researching }\end{array}$ & $\begin{array}{ll}\text { 1. Life-long Learning } \\
\text { 2. Knowledge Management }\end{array}$ \\
\hline & $\begin{array}{lll}\text { 2. } & \text { Creating and } \\
\text { Innovating }\end{array}$ & $\begin{array}{ll}\text { 1. } & \text { Innovating } \\
\text { 2. } & \text { Creativity } \\
\text { 3. } & \text { Critical Thinking } \\
\text { 4. } & \text { Change Management }\end{array}$ \\
\hline & $\begin{array}{ll}\text { 3. } & \text { Formulating } \\
\text { Strategies } \\
\text { Concepts }\end{array}$ & $\begin{array}{ll}\text { 1. } & \text { Business Strategy } \\
\text { 2. } & \text { Abstraction Ability } \\
\text { 3. } & \text { Managing Complexity }\end{array}$ \\
\hline \multirow[t]{3}{*}{$\begin{array}{l}\text { F. Organizing and } \\
\text { Executing }\end{array}$} & $\begin{array}{lll}\text { 1. } & \text { Planning and } \\
\text { Organizing }\end{array}$ & $\begin{array}{ll}\text { 1. Project Management } \\
\text { 2. Planning and Organizing } \\
\text { Work } \\
\text { 3. Management Ability }\end{array}$ \\
\hline & $\begin{array}{l}\text { 2. Delivering Results } \\
\text { and Meeting } \\
\text { Customer } \\
\text { Expectations }\end{array}$ & $\begin{array}{ll}\text { 1. } & \text { Customer Orientation } \\
\text { 2. } & \text { Customer } \quad \text { Relationship } \\
& \text { Management }\end{array}$ \\
\hline & $\begin{array}{ll}\text { 3. } & \text { Following } \\
& \text { Instructions anc } \\
\text { Procedures }\end{array}$ & $\begin{array}{ll}\text { 1. } & \text { Legislation Awareness } \\
\text { 2. } & \text { Safety Awareness } \\
\text { 3. } & \text { Individual Responsibility }\end{array}$ \\
\hline \multirow[t]{2}{*}{$\begin{array}{l}\text { G. Adapting and } \\
\text { Coping }\end{array}$} & $\begin{array}{l}\text { 1. Adapting } \\
\text { Responding and } \\
\text { Change }\end{array}$ & $\begin{array}{ll}\text { 1. Work in Interdisciplinary } \\
\text { Environments } \\
\text { 2. Intercultural Competency } \\
\text { 3. Flexibility } \\
\text { 4. Adaptability and Ability to } \\
\text { Change Mind-set }\end{array}$ \\
\hline & $\begin{array}{lll}\text { 2. } & \text { Persuading and } \\
& \text { Influencing }\end{array}$ & 1. Work-Life Balance \\
\hline \multirow[t]{2}{*}{$\begin{array}{l}\text { H. Enterprising and } \\
\text { Performing }\end{array}$} & $\begin{array}{l}\text { 1. Achieving Personal } \\
\text { Work Goals and } \\
\text { Objectives }\end{array}$ & $\begin{array}{l}\text { 1. Self-management } \\
\text { organization }\end{array}$ \\
\hline & $\begin{array}{l}\text { 2. Entrepreneurial and } \\
\text { Commercial } \\
\text { Thinking } \\
\end{array}$ & $\begin{array}{ll}\text { 1. } & \text { Business } \\
\text { Understanding } \\
\text { 2. } & \text { Entrepreneurship }\end{array}$ \\
\hline
\end{tabular}

Sumber : modifikasi dari Prifti et al., 2017

Hasil Point-to-point Correlation menunjukkan bahwa Big Eight competency dan 20 dimensi kompetensi (Competency Dimensions) dapat digunakan sebagai kaji ulang dengan mengingat bahwa dua tingkat kompetensi ini merupakan kompetensi umum yang wajib dimiliki oleh setiap karyawan. Sementara itu untuk kompetensi industri 4.0 (tingkat ketiga) dalam dimensi kompetensi Applying Expertise and Technology, menunjukkan bahwa hanya 3 (tiga) kompetensi berupa IT and Technology Affinity, Economics, Extract
Business Value from Social Media yang memiliki kaitan dengan SKKNI Industri Alas Kaki, Pengawetan Kulit dan Penyamakan Kulit. Sedangkan kompetensi selebihnya dalam dimensi kompetensi Applying Expertise and Technology merupakan kompetensi yang telah diatur dalam SKKNI yang berkaitan dengan teknologi informasi.

\section{Focus group discussion}

Untuk mengevaluasi lebih lanjut hasil point-to-point correlation, maka Focus group discussion dilakukan dengan 
melibatkan Lembaga Sertifikasi Profesi Pihak Pertama (LSP P1), perwakilan Program Studi di Lingkungan Politeknik ATK Yogyakarta dan jajaran Manajemen Politeknik ATK Yogyakarta. Kompetensi industri 4.0 sejumlah 49 (empat puluh sembilan) kompetensi yang merupakan hasil point-to-point correlation disandingkan dengan Elemen kompetensi dan kriteria unjuk kerja yang termuat dalam SKKNI Industri Alas Kaki, SKKNI Industri Pengawetan Kulit, dan SKKNI Industri Penyamakan Kulit. Elemen kompetensi dan kriteria unjuk kerja dalam SKKNI dipilih karena merupakan bagian dari unit kompetensi yang mendeskripsikan aktivitas yang harus dikerjakan untuk mencapai suatu unit kompetensi. Catatan dalam penelitan ini adalah Prifti et, al menggunakan pendekatan perilaku dalam menentukan kompetensi industri 4.0 sementara kompetensi yang termuat dalam SKKNI lebih menggunakan pendekatan fungsi. Sebagaimana diketahui bahwa SKKNI disusun dalam susunan fungsi pekerjaan yang mencakup 1) tujuan utama (main purpose), 2) fungsi kunci (key function) dari tujuan utama (main purpose), 3) fungsi utama (major function) dari fungsi kunci (key function); dan 4) fungsi dasar (basic function) dari fungsi utama serta diidentifikasi sebagai unit kompetensi. Pendekatan fungsi dalam kompetensi didefinisikan oleh Prifti et, al (2017) sebagai:

"The functional approach focuses on competencies as requirements for successfully fulfilling a task by restricting the term of competencies to the skills and know-how required for conducting a task".

Meskipun ada pendekatan kompetensi yang berbeda, model kompetensi industri 4.0 masih dapat digunakan dalam kajian ini dengan mengingat bahwa pendekatan perilaku dapat berlaku secara universal, dan persyaratan perilaku serupa dapat ditemukan di berbagai jenis pekerjaan.
Hal ini sesuai dengan rumusan SKKNI yang seharusnya memuat rumusan tentang kompetensi tugas, kompetensi manajemen tugas,kompetensi menghadapi keadaan darurat dan kompetensi menyesuaikan diri dengan lingkungan kerja, termasuk tanggung jawab dan bekerja sama dengan orang lain. Dengan demikian Focus group discussion berfokus untuk mengkaji muatan yang tersurat dalam tiap-tiap unit kompetensi pada SKKNI Industri Alas Kaki, SKKNI Industri Pengawetan Kulit, dan SKKNI Industri Penyamakan Kulit.

Hasil Focus group discussion menunjukkan bahwa secara eksplisit belum semua kompetensi industri 4.0 diakomodir oleh elemen kompetensi yang termuat dalam SKKNI Industri Alas Kaki, SKKNI Industri Pengawetan Kulit, dan SKKNI Industri Penyamakan Kulit. Dari 49 (empat puluh sembilan) kompetensi Industri 4.0 yang dimodifikasi dari Prifti et al., sebanyak 43 (empat puluh tiga) kompetensi telah terakomodir oleh SKKNI Industri Penyamakan Kulit. SKKNI Industri Alas Kaki telah mengakomodir 39 (tiga puluh sembilan) kompetensi industri 4.0. Sementara itu SKKNI Industri Pengawetan Kulit tampaknya menjadi SKKNI yang belum banyak mengakomodir kompetensi Industri 4.0, sebanyak 18 (delapan belas) kompetensi industri 4.0 baru termuat dalam elemen kompetensi. Focus group discussion juga menunjukkan bahwa ada 5 (lima) kompetensi industri 4.0 yang secara eksplisit belum terakomodir oleh SKKNI Industri Alas Kaki, SKKNI Industri Pengawetan Kulit, maupun SKKNI Industri Penyamakan Kulit. Kompetensi tersebut berupa 1) Extract Business Value from Social Media, 2) Abstraction Ability, 3) Work in Interdisciplinary Environments, 4) Intercultural Competency dan 5) WorkLife Balance.

Bagian paling mencolok terdapat pada dimensi kompetensi berupa Adapting and Coping: Adapting and Responding to Change, Persuading and Influencing yang 
nyaris tidak terpenuhi di ketiga SKKNI. Kewirausahaan juga belum diakomodir dalam SKKNI sehingga kompetensi berupa Extract Business Value from Social Media belum secara eksplisit termuat dalam unit kompetensi SKKNI.

Tabel 2. Korelasi Kompetensi Industri 4.0 dengan SKKNI

\begin{tabular}{|c|c|c|c|c|c|c|}
\hline \multirow[t]{2}{*}{$\begin{array}{l}\text { Competency } \\
\text { Dimensions }\end{array}$} & \multicolumn{2}{|c|}{$\begin{array}{c}\text { SKKNI } \\
\text { Industri Alas Kaki }\end{array}$} & \multicolumn{2}{|c|}{$\begin{array}{c}\text { SKKNI } \\
\text { Industri Pengawetan Kulit }\end{array}$} & \multicolumn{2}{|c|}{$\begin{array}{c}\text { SKKNI } \\
\text { Industri Penyamakan Kulit }\end{array}$} \\
\hline & $\begin{array}{c}\text { Elemen } \\
\text { Kompetensi }\end{array}$ & $\begin{array}{l}\text { Unjuk Kerja } \\
\text { Kompetensi }\end{array}$ & $\begin{array}{c}\text { Elemen } \\
\text { Kompetensi }\end{array}$ & $\begin{array}{l}\text { Unjuk Kerja } \\
\text { Kompetensi }\end{array}$ & $\begin{array}{c}\text { Elemen } \\
\text { Kompetensi }\end{array}$ & $\begin{array}{l}\text { Unjuk Kerja } \\
\text { Kompetensi }\end{array}$ \\
\hline $\begin{array}{l}\text { A.1.1 } \\
\text { A.1.2 }\end{array}$ & $\begin{array}{l}\text { - } \quad \text { Ada } \\
\text { - } \quad \text { Ada }\end{array}$ & $\begin{array}{ll}\text { - } & \text { Jelas } \\
\text { - } & \text { Jelas }\end{array}$ & $\begin{array}{ll}\text { - } & \text { Ada } \\
\text { - } & \text { Ada }\end{array}$ & $\begin{array}{ll}- & \text { Jelas } \\
\text { - } & \text { Jelas }\end{array}$ & $\begin{array}{ll}- & \text { Ada } \\
\text { - } & \text { Ada }\end{array}$ & $\begin{array}{ll}\text { - } & \text { Jelas } \\
\text { - } & \text { Jelas }\end{array}$ \\
\hline A.2.1 & - $\quad$ Ada & - $\quad$ Jelas & - $\quad$ Tidak & $\begin{array}{ll}\text { - } & \text { Tidak }\end{array}$ & - $\quad$ Ada & - $\quad$ Jelas \\
\hline $\begin{array}{l}\text { B.1.1 } \\
\text { B.1.2 } \\
\text { B.1.3 } \\
\end{array}$ & $\begin{array}{ll}\text { - } & \text { Ada } \\
\text { - } & \text { Ada } \\
\text { - } & \text { Ada } \\
\end{array}$ & $\begin{array}{ll}\text { - } & \text { Jelas } \\
\text { - } & \text { Jelas } \\
\text { - } & \text { Jelas } \\
\end{array}$ & $\begin{array}{ll}\text { - } & \text { Ada } \\
\text { - } & \text { Ada } \\
\text { - } & \text { Ada } \\
\end{array}$ & $\begin{array}{ll}\text { - } & \text { Tidak } \\
\text { - } & \text { Jelas } \\
\text { - } & \text { Jelas } \\
\end{array}$ & $\begin{array}{ll}\text { - } & \text { Ada } \\
\text { - } & \text { Ada } \\
\text { - } & \text { Ada } \\
\end{array}$ & $\begin{array}{ll}\text { - } & \text { Jelas } \\
\text { - } & \text { Jelas } \\
\text { - } & \text { Jelas } \\
\end{array}$ \\
\hline $\begin{array}{l}\text { B.2.1 } \\
\text { B.2.2 } \\
\text { B.2.3 }\end{array}$ & $\begin{array}{ll}\text { - } & \text { Tidak } \\
\text { - } & \text { Ada } \\
\text { - } & \text { Ada } \\
\end{array}$ & $\begin{array}{ll}\text { - } & \text { Tidak } \\
\text { - } & \text { Jelas } \\
\text { - } & \text { Jelas } \\
\end{array}$ & $\begin{array}{ll}\text { - } & \text { Tidak } \\
\text { - } & \text { Ada } \\
\text { - } & \text { Tidak } \\
\end{array}$ & $\begin{array}{ll}\text { - } & \text { Tidak } \\
\text { - } & \text { Ada } \\
\text { - } & \text { Tidak } \\
\end{array}$ & $\begin{array}{ll}\text { - } & \text { Ada } \\
\text { - } & \text { Ada } \\
\text { - } & \text { Tidak } \\
\end{array}$ & $\begin{array}{ll}\text { - } & \text { Tidak } \\
\text { - } & \text { Jelas } \\
\text { - } & \text { Tidak } \\
\end{array}$ \\
\hline $\begin{array}{l}\text { C.1.1 } \\
\text { C.1.2 } \\
\text { C.1.3 }\end{array}$ & $\begin{array}{ll}\text { - } & \text { Ada } \\
\text { - } & \text { Ada } \\
\text { - } & \text { Tidak } \\
\end{array}$ & $\begin{array}{ll}\text { - } & \text { Jelas } \\
\text { - } & \text { Tidak } \\
\text { - } & \text { Tidak } \\
\end{array}$ & $\begin{array}{ll}\text { - } & \text { Tidak } \\
\text { - } & \text { Tidak } \\
\text { - } & \text { Tidak } \\
\end{array}$ & $\begin{array}{ll}\text { - } & \text { Tidak } \\
\text { - } & \text { Tidak } \\
\text { - } & \text { Tidak } \\
\end{array}$ & $\begin{array}{ll}\text { - } & \text { Ada } \\
\text { - } & \text { Ada } \\
\text { - } & \text { Ada } \\
\end{array}$ & $\begin{array}{ll}\text { - } & \text { Jelas } \\
\text { - } & \text { Jelas } \\
\text { - } & \text { Jelas } \\
\end{array}$ \\
\hline $\begin{array}{l}\text { C.2.1 } \\
\text { C. } 2.2 \\
\end{array}$ & $\begin{array}{ll}\text { - } & \text { Ada } \\
\text { - } & \text { Tidak } \\
\end{array}$ & $\begin{array}{ll}\text { - } & \text { Tidak } \\
\text { - } & \text { Tidak } \\
\end{array}$ & $\begin{array}{ll}\text { - } & \text { Tidak } \\
\text { - } & \text { Tidak } \\
\end{array}$ & $\begin{array}{ll}\text { - } & \text { Tidak } \\
\text { - } & \text { Tidak } \\
\end{array}$ & $\begin{array}{ll}\text { - } & \text { Ada } \\
\text { - } & \text { Ada } \\
\end{array}$ & $\begin{array}{ll}\text { - } & \text { Jelas } \\
\text { - } & \text { Tidak } \\
\end{array}$ \\
\hline C.3.1 & - $\quad$ Ada & - $\quad$ Jelas & - $\quad$ Ada & - $\quad$ Tidak & - $\quad$ Ada & - $\quad$ Jelas \\
\hline $\begin{array}{l}\text { D.1.1 } \\
\text { D.1.2 }\end{array}$ & $\begin{array}{ll}\text { - } & \text { Ada } \\
\text { - } & \text { Ada }\end{array}$ & $\begin{array}{ll}- & \text { Jelas } \\
\text { - } & \text { Jelas }\end{array}$ & $\begin{array}{ll}\text { - } & \text { Tidak } \\
\text { - } & \text { Tidak } \\
\end{array}$ & $\begin{array}{ll}\text { - } & \text { Tidak } \\
\text { - } & \text { Tidak } \\
\end{array}$ & $\begin{array}{ll}\text { - } & \text { Ada } \\
\text { - } & \text { Ada }\end{array}$ & $\begin{array}{ll}\text { - } & \text { Jelas } \\
\text { - } & \text { Jelas }\end{array}$ \\
\hline $\begin{array}{l}\text { D.2.1 } \\
\text { D.2.2 } \\
\text { D.2.3 }\end{array}$ & $\begin{array}{ll}\text { - } & \text { Ada } \\
\text { - } & \text { Ada } \\
\text { - } & \text { Tidak } \\
\end{array}$ & $\begin{array}{ll}\text { - } & \text { Jelas } \\
\text { - } & \text { Jelas } \\
\text { - } & \text { Tidak } \\
\end{array}$ & $\begin{array}{ll}\text { - } & \text { Tidak } \\
\text { - } & \text { Tidak } \\
\text { - } & \text { Tidak } \\
\end{array}$ & $\begin{array}{ll}\text { - } & \text { Tidak } \\
\text { - } & \text { Tidak } \\
\text { - } & \text { Tidak } \\
\end{array}$ & $\begin{array}{ll}\text { - } & \text { Ada } \\
\text { - } & \text { Ada } \\
\text { - } & \text { Tidak } \\
\end{array}$ & $\begin{array}{ll}\text { - } & \text { Tidak } \\
\text { - } & \text { Jelas } \\
\text { - } & \text { Tidak } \\
\end{array}$ \\
\hline $\begin{array}{l}\text { D.3.1 } \\
\text { D.3.2 } \\
\text { D.3.3 } \\
\text { D.3.4 }\end{array}$ & $\begin{array}{ll}\text { - } & \text { Ada } \\
\text { - } & \text { Ada } \\
\text { - } & \text { Ada } \\
\text { - } & \text { Ada } \\
\end{array}$ & $\begin{array}{ll}\text { - } & \text { Jelas } \\
\text { - } & \text { Jelas } \\
\text { - } & \text { Jelas } \\
\text { - } & \text { Jelas } \\
\end{array}$ & $\begin{array}{ll}\text { - } & \text { Ada } \\
\text { - } & \text { Tidak } \\
\text { - } & \text { Ada } \\
\text { - } & \text { Tidak } \\
\end{array}$ & $\begin{array}{ll}\text { - } & \text { Ada } \\
\text { - } & \text { Tidak } \\
\text { - } & \text { Ada } \\
\text { - } & \text { Tidak } \\
\end{array}$ & $\begin{array}{ll}\text { - } & \text { Ada } \\
\text { - } & \text { Ada } \\
\text { - } & \text { Ada } \\
\text { - } & \text { Ada } \\
\end{array}$ & $\begin{array}{ll}\text { - } & \text { Jelas } \\
\text { - } & \text { Jelas } \\
\text { - } & \text { Jelas } \\
\text { - } & \text { Jelas } \\
\end{array}$ \\
\hline $\begin{array}{l}\text { E.1.1 } \\
\text { E.1.2 }\end{array}$ & $\begin{array}{ll}\text { - } & \text { Tidak } \\
\text { - } & \text { Ada }\end{array}$ & $\begin{array}{ll}\text { - } & \text { Tidak } \\
\text { - } & \text { Tidak } \\
\end{array}$ & $\begin{array}{ll}\text { - } & \text { Tidak } \\
\text { - } & \text { Tidak } \\
\end{array}$ & $\begin{array}{ll}\text { - } & \text { Tidak } \\
\text { - } & \text { Tidak } \\
\end{array}$ & $\begin{array}{ll}\text { - } & \text { Ada } \\
\text { - } & \text { Ada }\end{array}$ & $\begin{array}{ll}\text { - } & \text { Tidak } \\
\text { - } & \text { Tidak } \\
\end{array}$ \\
\hline $\begin{array}{l}\text { E.2.1 } \\
\text { E.2.2 } \\
\text { E.2.3 } \\
\text { E.2.4 }\end{array}$ & $\begin{array}{ll}\text { - } & \text { Ada } \\
\text { - } & \text { Ada } \\
\text { - } & \text { Ada } \\
\text { - } & \text { Ada }\end{array}$ & $\begin{array}{ll}\text { - } & \text { Jelas } \\
\text { - } & \text { Jelas } \\
\text { - } & \text { Tidak } \\
\text { - } & \text { Tidak } \\
\end{array}$ & $\begin{array}{ll}\text { - } & \text { Tidak } \\
\text { - } & \text { Tidak } \\
\text { - } & \text { Tidak } \\
\text { - } & \text { Tidak } \\
\end{array}$ & $\begin{array}{ll}\text { - } & \text { Tidak } \\
\text { - } & \text { Tidak } \\
\text { - } & \text { Tidak } \\
\text { - } & \text { Tidak } \\
\end{array}$ & $\begin{array}{ll}\text { - } & \text { Ada } \\
\text { - } & \text { Ada } \\
\text { - } & \text { Ada } \\
\text { - } & \text { Ada }\end{array}$ & $\begin{array}{ll}\text { - } & \text { Jelas } \\
\text { - } & \text { Jelas } \\
\text { - } & \text { Tidak } \\
\text { - } & \text { Tidak } \\
\end{array}$ \\
\hline $\begin{array}{l}\text { E.3.1 } \\
\text { E.3.2 } \\
\text { E.3.3 }\end{array}$ & $\begin{array}{ll}\text { - } & \text { Ada } \\
\text { - } & \text { Tidak } \\
\text { - } & \text { Ada } \\
\end{array}$ & $\begin{array}{ll}\text { - } & \text { Tidak } \\
\text { - } & \text { Tidak } \\
\text { - } & \text { Tidak } \\
\end{array}$ & $\begin{array}{ll}\text { - } & \text { Tidak } \\
\text { - } & \text { Tidak } \\
\text { - } & \text { Tidak } \\
\end{array}$ & $\begin{array}{ll}\text { - } & \text { Tidak } \\
\text { - } & \text { Tidak } \\
\text { - } & \text { Tidak } \\
\end{array}$ & $\begin{array}{ll}\text { - } & \text { Ada } \\
\text { - } & \text { Tidak } \\
\text { - } & \text { Ada } \\
\end{array}$ & $\begin{array}{ll}\text { - } & \text { Tidak } \\
\text { - } & \text { Tidak } \\
\text { - } & \text { Tidak } \\
\end{array}$ \\
\hline $\begin{array}{l}\text { F.1.1 } \\
\text { F.1.2 } \\
\text { F.1.3 }\end{array}$ & $\begin{array}{ll}\text { - } & \text { Ada } \\
\text { - } & \text { Ada } \\
\text { - } & \text { Ada } \\
\end{array}$ & $\begin{array}{ll}\text { - } & \text { Jelas } \\
\text { - } & \text { Jelas } \\
\text { - } & \text { Jelas } \\
\end{array}$ & $\begin{array}{ll}\text { - } & \text { Tidak } \\
\text { - } & \text { Ada } \\
\text { - } & \text { Ada } \\
\end{array}$ & $\begin{array}{ll}\text { - } & \text { Tidak } \\
\text { - } & \text { Jelas } \\
\text { - } & \text { Tidak } \\
\end{array}$ & $\begin{array}{ll}\text { - } & \text { Ada } \\
\text { - } & \text { Ada } \\
\text { - } & \text { Ada } \\
\end{array}$ & $\begin{array}{ll}\text { - } & \text { Jelas } \\
\text { - } & \text { Jelas } \\
\text { - } & \text { Jelas } \\
\end{array}$ \\
\hline $\begin{array}{l}\text { F.2.1 } \\
\text { F.2.2 } \\
\end{array}$ & $\begin{array}{ll}\text { - } & \text { Ada } \\
\text { - } & \text { Ada } \\
\end{array}$ & $\begin{array}{ll}\text { - } & \text { Jelas } \\
\text { - } & \text { Tidak } \\
\end{array}$ & $\begin{array}{ll}\text { - } & \text { Tidak } \\
\text { - } & \text { Tidak } \\
\end{array}$ & $\begin{array}{ll}\text { - } & \text { Tidak } \\
\text { - } & \text { Tidak } \\
\end{array}$ & $\begin{array}{ll}\text { - } & \text { Ada } \\
\text { - } & \text { Ada } \\
\end{array}$ & $\begin{array}{ll}\text { - } & \text { Jelas } \\
\text { - } & \text { Tidak } \\
\end{array}$ \\
\hline $\begin{array}{l}\text { F.3.1 } \\
\text { F.3.2 } \\
\text { F.3.3 }\end{array}$ & $\begin{array}{ll}\text { - } & \text { Tidak } \\
\text { - } & \text { Ada } \\
\text { - } & \text { Ada } \\
\end{array}$ & $\begin{array}{ll}\text { - } & \text { Tidak } \\
\text { - } & \text { Jelas } \\
\text { - } & \text { Tidak } \\
\end{array}$ & $\begin{array}{ll}\text { - } & \text { Ada } \\
\text { - } & \text { Ada } \\
\text { - } & \text { Ada } \\
\end{array}$ & $\begin{array}{ll}\text { - } & \text { Tidak } \\
\text { - } & \text { Jelas } \\
\text { - } & \text { Jelas } \\
\end{array}$ & $\begin{array}{ll}\text { - } & \text { Tidak } \\
\text { - } & \text { Ada } \\
\text { - } & \text { Ada } \\
\end{array}$ & $\begin{array}{ll}\text { - } & \text { Tidak } \\
\text { - } & \text { Jelas } \\
\text { - } & \text { Tidak } \\
\end{array}$ \\
\hline $\begin{array}{l}\text { G.1.1 } \\
\text { G.1.2 } \\
\text { G.1.3 }\end{array}$ & $\begin{array}{ll}\text { - } & \text { Tidak } \\
\text { - } & \text { Tidak } \\
\text { - } & \text { Ada } \\
\end{array}$ & $\begin{array}{ll}\text { - } & \text { Tidak } \\
\text { - } & \text { Tidak } \\
\text { - } & \text { Jelas } \\
\end{array}$ & $\begin{array}{ll}\text { - } & \text { Tidak } \\
\text { - } & \text { Tidak } \\
\text { - } & \text { Tidak } \\
\end{array}$ & $\begin{array}{ll}\text { - } & \text { Tidak } \\
\text { - } & \text { Tidak } \\
\text { - } & \text { Tidak } \\
\end{array}$ & $\begin{array}{ll}\text { - } & \text { Tidak } \\
\text { - } & \text { Tidak } \\
\text { - } & \text { Ada } \\
\end{array}$ & $\begin{array}{ll}\text { - } & \text { Tidak } \\
\text { - } & \text { Tidak } \\
\text { - } & \text { Jelas } \\
\end{array}$ \\
\hline
\end{tabular}

Secara, pemetaan elemen kompetensi dan unjuk kerja kompetensi dalam SKKNI terhadap kompetensi model industri 4.0 adalah sebagaimana tampak dalam tabel 2. 


\begin{tabular}{|l|cl|cl|cl|ll|lllll|}
\hline G.1.4 & $\bullet$ & Ada & $\bullet$ & Tidak & $\bullet$ & Tidak & $\bullet$ & Tidak & $\bullet$ & Ada & $\bullet$ & Tidak \\
\hline G.2.1 & $\bullet$ & Tidak & $\bullet$ & Tidak & $\bullet$ & Tidak & $\bullet$ & Tidak & $\bullet$ & Tidak & $\bullet$ & Tidak \\
\hline H.1.1 & $\bullet$ & Ada & $\bullet$ & Tidak & $\bullet$ & Ada & $\bullet$ & Tidak & $\bullet$ & Ada & $\bullet$ & Jelas \\
\hline H.2.1 & $\bullet$ & Ada & $\bullet$ & Jelas & $\bullet$ & Ada & $\bullet$ & Jelas & $\bullet$ & Ada & $\bullet$ & Jelas \\
H.2.2 & $\bullet$ & Ada & $\bullet$ & Tidak & $\bullet$ & Ada & $\bullet$ & Tidak & $\bullet$ & Ada & $\bullet$ & Jelas \\
\hline
\end{tabular}

\section{KESIMPULAN}

Kesimpulan yang diperoleh adalah sebagai berikut:

1. Hasil point-to-point correlation antara model kompetensi industri 4.0 yang dikembangkan oleh Prifti, et, al, sebanyak 49 (empat puluh sembilan) kompetensi memiliki relevansi untuk digunakan dalam bahan kaji ulang SKKNI.

2. SKKNI menggunakan pendekatan fungsional dalam penyusunan kompetensi, hal ini berbeda dengan pendekatan kompetensi industri 4.0 yang dikembangkan oleh Prifti, et, al yang menggunakan pendekatan perilaku, sehingga focus group discusion dilakukan dengan menggunakan kompetensi yang tersurat pada SKKNI Industri Alas Kaki, SKKNI Industri Pengawetan Kulit, maupun SKKNI Industri Penyamakan Kulit.

3. Belum semua model kompetensi industri 4.0 diakomdir dalam SKKNI Industri Alas Kaki, SKKNI Industri Pengawetan Kulit, maupun SKKNI Industri Penyamakan Kulit.

4. Pengukuran lanjutan kompetensi melalui pendekatan fungsional maka perlu melihat materi uji kompetensi, dan kondisi saat ini belum semua unit kompetensi dalam SKKNI Industri Alas Kaki, SKKNI Industri Pengawetan Kulit, maupun SKKNI Industri Penyamakan Kulit memiliki materi uji kompetensi.

\section{DAFTAR PUSTAKA}

Bartram, D. (2005). The great eight competencies: A criterion-centric approach to validation. Journal of Applied Psychology, 90(6), 1185-
1203. https://doi.org/10.1037/00219010.90.6.1185

Bartram, D. (2012). The SHL universal competency framework. The CEB Talent Measurement Solution, 1-10. Enke, J., Glass, R., Kreß, A., Hambach, J., Tisch, M., \& Metternich, J. (2018). Industrie 4.0 - Competencies for a modern production system: A curriculum for Learning Factories. Procedia Manufacturing, 23(2017), 267-272.

https://doi.org/10.1016/J.PROMFG. 2018.04.028

Gareta, S. P. (2018). Peta jalan "Making Indonesia 4.0" resmi meluncur. Retrieved June 24, 2018, from https://www.antaranews.com/berita/ 698406/peta-jalan-makingindonesia-40-resmi-meluncur

Jackson, D. (2010). An international profile of industry-relevant competencies and skill gaps in modern graduates. The International Journal of Management Education, 8(3), 29-58. https://doi.org/10.3794/ijme.83.288

Jatmiko, B. P. (2018). Sekitar 50 Juta Pekerjaan di Indonesia Akan Hilang dalam Beberapa Waktu ke Depan. Retrieved June 23, 2018, from https://ekonomi.kompas.com/read/2 018/02/06/143831926/sekitar-50juta-pekerjaan-di-indonesia-akanhilang-dalam-beberapa-waktu-ke Kagermann, H., Wahlster, W., \& Helbig, J. (2013). Recommendations for implementing the strategic initiative INDUSTRIE 4.0. Final report of the Industrie 4.0 Working Group. https://doi.org/10.13140/RG.2.1.120 5.8966 
Kementerian Ketenagakerjaan. Keputusan

Menteri Ketenagakerjaan Nomor

111 Tahun 2016 Tentang Penetapan

Standar Kompetensi Kerja Nasional

Indonesia Kategori Industri

Pengolahan Golongan Pokok Industri Kulit, Barang Dari Kulit Dan Alas Kaki Bidang Industri Penyamakan Kulit Subbidang Pro (2016). Indonesia.

Kementerian Ketenagakerjaan. Keputusan

Menteri Ketenagakerjaan Nomor

112 Tahun 2016 Tentang Penetapan

Standar Kompetensi Kerja Nasional Indonesia Kategori Industri Pengolahan Golongan Pokok Industri Kulit, Barang Dari Kulit dan Alas Kaki Bidang Industri Alas Kaki (2016). Indonesia.

Kementerian Tenaga Kerja dan Transmigrasi. Keputusan Menteri Tenaga Kerja dan Transmigrasi Nomor 147 Tahun 2013 Tentang Penetapan Standar Kompetensi Kerja Nasional Indonesia Kategori Industri Pengolahan, Golongan Pokok Industri Kulit dan Alas Kaki, Golongan Industri Kulit dan Barang Dari Kulit, Te (2013). Indonesia.

Milagros Diaz Bermudez, B. F. J. (2017).

Competencies to adopt Industry 4 . 0 for operations management personnel at automotive parts suppliers in Nuevo Leon. Proceedings of the International Conference on Industrial Engineering and Operations Management Bogota, Volombia, 736-747.

Prifti, L., Knigge, M., Kienegger, H., \& Krcmar, H. (2017). A Competency Model for "Industrie 4.0" Employees. 13th International Conference on Wirtschaftsinformatik, 46-60.

Sekretaris Negara Republik Indonesia. Undang-undang Nomor 13 Tahun 2003 Tentang Ketenagakerjaan (2003). Indonesia.
Williams, C. (2005). The discursive construction of the "competent" learner-worker: From key competencies to "employability skills." Studies in Continuing Education, 27(1), 33-49. https://doi.org/10.1080/0158037050 $\underline{0056422}$ 
